\title{
A Review on the Classification of Students' Interaction in Online Social Collaborative Problem-based Learning Environment: How Can We Enhance the Students' Online Interaction?
}

\author{
Wan Nur Tasnim Wan Hussin*, Jamalludin Harun, Nurbiha A. Shukor \\ Faculty of Social Sciences and Humanities, School of Education, Universiti Teknologi Malaysia, Johor, Malaysia
}

Received July 9, 2019; Revised September 9, 2019; Accepted September 16, 2019

Copyright $@ 2019$ by authors, all rights reserved. Authors agree that this article remains permanently open access under the terms of the Creative Commons Attribution License 4.0 International License

\begin{abstract}
Purpose: The interaction between students during online learning is a growing concern of researchers today. Following the principle of educational psychology, a collaborative learning approach incorporates online learning activities to encourage active interaction and to cultivate problem-solving abilities via students' discussion. This study aims to identify the classification of students' interaction in the online social collaborative problem-based learning environment and the strategies to enhance online interaction. Methodology: The literature search was performed using the following electronic databases: Elsevier (ScienceDirect), Springer, Google Scholar, IEEE Xplore, SAGE, Emerald Insight, Taylor and Francis, ERIC and Scopus and Wiley Online Library for all papers published between 1989 and 2019. The initial search yielded 129 published articles. After screening and eligibility assessment, 28 articles were included in the review. Main Findings: The types of interaction among students included learner-learner, learner-instructor, learner-content, learner-interface, and learner-self. Less common types of interaction included learner-instruction, learner-environment, and learner-tool. Most researchers focused only on student-student interaction, especially studies between 2017 to 2019. As for improvement strategies, some papers focused on specific learner's interaction whereas others only outlined the general strategy without specifying the type of learner's interaction. Applications: Interaction is an important element of online learning. Activities involved in the active interaction among students such as sharing of ideas, discussion, negotiation, and opinion exchanges can improve their knowledge and thinking skills. As the student-centred approach in improving learning experience is gaining popularity, findings from this study
\end{abstract}

can be incorporated into today's education system to enhance students' interaction during online learning. Novelty/Originality: The results from this study will contribute to the existing literature on the types of interactions during online learning and strategies to improve students' interaction. We hope that this study enhances the understanding of the various stakeholders on the importance of effective interaction among students in the online learning environment towards the development of the thinking skills of our students.

Keywords Types of Learner Interaction, Online Learning, Social Learning, Collaborative, Problem-based Learning, Strategy in Interaction

\section{Introduction}

Many studies have proven that social interactions are a good approach for individual learning and collaborative learning, especially for higher education level (Vuopala, Hyvönen, \& Järvelä, 2016). Students learn better when they are able to interact effectively with teachers, other students, and subject content whether they are in a traditional classroom setting or online learning environment. In recent years, with technological advancement, the interaction between students and technology has been highlighted in many platforms, especially in an online learning environment. The impact of interaction on learning has been extensively studied before and researchers have consistently found that interactions are a key element for successful learning experiences be it in a traditional classroom setting or online 
learning environment (Mutalib, Halim, \& Yahaya, 2016). Furthermore, students in the higher education level are able to improve their communication skills when they work together to solve their group assignment problems. This represents a valuable experience in their education journey (Vuopala et al., 2016). However, to achieve successful collaborative learning, all of those who are involved need to understand the role and application of effective interaction in the learning process (Vuopala et al., 2016).

Collaborative learning is vital in building students' confidence during the learning process. With a good level of self-confidence, students will be able to solve problems that they encounter during learning (Fung, 2014). Learning in groups enables students to learn and hear what others have to say, to seek out an explanation for misconception, to help and support others, and eventually to build a learning-friendly knowledge foundation. In this process, students will learn to talk and reason among themselves in a mature way and this subsequently translates into a relationship that is based on unity, trust, and confidence. For students to be able to learn successfully with one another in a group setting, all the above-mentioned factors must be given serious attention (Gillies, 2017). However, it is important to take note that group learning methods do not always achieve the intended learning objectives. This is especially true if there is also a lack of a collaborative approach among the group members to actively participate in the learning process (Matcha \& Rambli, 2013). One of the commonly encountered disadvantages of collaborative learning is the unequal contribution of group members whereby some students tend to be "free riders" while others shoulder the responsibility to complete the group task (Baharudin \& Jamalludin, 2014).

In view of this, many strategies have been put forth to design a healthy learning environment that promotes effective collaborative interaction. It has been postulated that a problem-based learning strategy would enable students to collaborate effectively (Savery \& Duffy, 1995). This proposed approach included a learning strategy that would help the students to become more active in the learning process by motivating them to learn how to solve the real-world problem (Hulsman \& van der Vloodt, 2015). Researchers who have studied the effects of collaboration on problem-solving have found that such collaboration improved students' abilities in advanced thinking when they are encouraged to discuss the problems put forth to them and to suggest potential solutions $(\mathrm{Ku}$, Tseng, \& Akarasriworn, 2013). With the increasing evidence showing that collaborative learning is an effective learning strategy that enhances student interaction and facilitates in-depth understanding through clarification processes, many educators have incorporated collaborative problem-solving activities for the benefits of their students, even in the online learning environments (Kwon, Song, Sari, \& Khikmatillaeva, 2019). It is believed that the problem-based learning approach has the potential to overcome issues pertaining to interaction within the boundaries of collaborative learning.

However, collaborative learning based on problem-solving is not always fully effective. It may be hindered by a limited exchange of resources and activities which cannot be resolved during the class (Conejo, Barros, Guzmán, \& Garcia-Viñas, 2013). Interaction after class outside the classroom setting is vital in overcoming this limitation. Online social tools would be an ideal alternative as an online learning platform for the students to participate and contribute after class (Zulkifli, Abd Halim, \& Yahaya, 2018). Although many researches had been conducted on topics related to students' interaction in the process of learning, there is a need for more extensive research to compare the different types of interaction. Interactions between students are very important during their learning journey in the educational institutes as good interaction can be a means for the students to achieve relevant goals, from both personal and institutional perspectives. Students' interaction is an important unit of analysis in the context of online learning. Thus, further research is warranted to explore these interactions across a variety of learning platforms and strategies in an online environment (Saadatmand, Uhlin, Hedberg, Åbjörnsson, \& Kvarnström, 2017). In view of this, this study aims to identify the classification of students' interactions in an online collaborative learning setting and to determine how to improve students' interaction in the online problem-based learning environment.

\section{Methodology}

To fulfill the objectives of the research, we limited the search to studies relevant to students' interaction. The following inclusion criteria are applied: the study focused on the interaction during online learning education process and the article must contain the type of learners' interaction, and the study must be published in English language.

The literature search was performed using the following electronic databases: Elsevier (ScienceDirect), Springer, Google Scholar, IEEE Xplore, SAGE, Emerald Insight, Taylor and Francis, ERIC and Scopus and Wiley Online Library. We used the following terms in the search strategy: interaction, interaction online learning, social interaction, online interactions, type of learner interaction, increasing interaction in social learning environment, learner computer interaction, collaborative interaction, and interaction in problem-based learning. No restrictions on publication date were considered as we intended to evaluate the trend of the type of learner interaction over the years.

The initial search yielded 129 articles published between 1989 and 2019. After screening and eligibility assessment, 28 articles were included in the final review. Table 1 shows the database source, initial and final numbers of articles selected from the respective databases. 
Table 1. Distribution of Papers by Online Database

\begin{tabular}{|c|c|c|}
\hline Database & Candidates & Final Selection \\
\hline Elsevier (ScienceDirect) & 26 & 9 \\
\hline Springer & 18 & 4 \\
\hline Google Scholar & 17 & 3 \\
\hline IEEE Xplore & 16 & 3 \\
\hline SAGE & 11 & 2 \\
\hline Emerald insight & 13 & 2 \\
\hline Taylor and Francis & 9 & 2 \\
\hline ERIC & 10 & 1 \\
\hline Scopus & 5 & 0 \\
\hline Wiley Online Library & 4 & $\mathbf{2 8}$ \\
\hline Total & $\mathbf{1 2 9}$ & \\
\hline
\end{tabular}

\section{Findings and Discussion: Type of Interaction in Online Social Learning}

From the 28 reviewed articles, we are able to categorize the types of students' interaction reported by previous researchers. Moore (1989) was the first study to report on the 3 types of interactive relationships related to distance learning; namely interactions between learner-content, learner-instructor, and learner-learner. After that, Hillman, Willis, and Gunawardena (1994) suggested a fourth type of interaction; learner-interface. In a 1998 study, Soo and Bonk (1998) stated that self-regulation skills should be one of the most important learning objectives for online learning. Thus, learners should interact with themselves in order to conduct self-directed learning. Following that, Hirumi (2002) classified students' interaction into 4 types: learner-self, learner-human, learner-non human (content, interface, and environment), and learner-instruction. Based on all the previous studies, Chou, Peng, and Chang (2010) then proposed the 5 types of learners' interaction in the setting of online learning, which included learner-learner, learner-instructor, learner-content, learner-interface, and learner-self. Similar to this 2010 study, Aqel (2013) and Prestridge (2014) focused on the same types of interactions except for the exclusion of learner-self interaction.

In a few other studies, Rhode (2009), Bernard et al. (2009) and Balaji and Chakrabarti (2010) focused on learner-learner, learner-instructor, and learner-content interactions. Similarly, the same interactions were the point of focus for another 3 studies published later on between 2011-2017 by Abrami, Bernard, Bures, Borokhovski, and Tamim (2011), Ping (2011), Mohammad, Sara, Zahra, and Mojtaba (2013) and Saadatmand et al. (2017). On top of these 3 above-mentioned interactions, Panchoo (2017) also focused an extra type of interactions, which was learner-tool interaction.

As for the remaining studies, the researchers mainly focus on 2 or a single type of students' interaction. For example, Meeuwisse, Severiens, and Born (2010) and Schallert et al. (2015) focused on the interaction between learner-learner and learner-instructor whereas Strickland and Xie (2012) focused on learner-learner interaction and learner-content interaction.

There were also a few papers which reported on only a single type of interaction.Zydney and Seo (2012); Jumaat and Tasir (2013) and Sarapin and Morris (2015)were the 3 published papers that focused only on learner-instructor interaction. Another 7 papers focused solely on learner-learner interaction, namely Kurucay and Inan (2017), Tawfik et al. (2017), Adraoui, Retbi, Idrissi, and Bennani (2017), Oyarzun, Stefaniak, Bol, and Morrison (2018), Annamalai (2018), Tawfik et al. (2018) and Hayashi (2019). The details of all the studies pertaining to online learning with their year of publication and type of learner interactions are shown in Table 2.

Table 2. Type of Learner Interaction in Online Social Learning

\begin{tabular}{|c|l|c|}
\hline Author (Year) & \multicolumn{1}{|c|}{ Purpose of Research } & *Type of Learner Interaction \\
\hline \multirow{2}{*}{ Moore (1989) } & To study the interaction for distance education & L-I \\
& & L-L \\
\hline \multirow{3}{*}{ Hillman et al. (1994) } & $\begin{array}{l}\text { To introduce the concept of learner-interface interaction and to suggest } \\
\text { methods that could increase the uptake of student knowledge in the } \\
\text { electronic classroom based on instructional design }\end{array}$ & L-IF \\
\hline \multirow{3}{*}{ Soo and Bonk (1998) } & To explain what kind of interaction is considered important for online & L-I \\
& distance learning & L-C \\
\hline \multirow{3}{*}{ Hirumi (2002) } & & L-S \\
& To posits a three-level framework for classifying e-learning interactions & L-H \\
& & L-NH \\
\hline \multirow{2}{*}{ Rhode (2009) } & To analyze the dynamics of interaction within a self-paced online learning & L-L \\
& environment & L-I \\
\hline
\end{tabular}




\begin{tabular}{|c|c|c|}
\hline $\begin{array}{l}\text { Meeuwisse et al. } \\
\text { (2010) }\end{array}$ & $\begin{array}{l}\text { To study a model for describing the relationships between the extent to } \\
\text { which learning environments are activating and students' interaction with } \\
\text { teachers and peers, a sense of belonging, and the success of learning }\end{array}$ & $\begin{array}{c}\text { L-L } \\
\text { L-I }\end{array}$ \\
\hline $\begin{array}{l}\text { Balaji and Chakrabarti } \\
\text { (2010) }\end{array}$ & To explore if online discussion forum is effective in aiding student learning & $\begin{array}{l}\text { L-L } \\
\text { L-I } \\
\text { L-C }\end{array}$ \\
\hline Chou et al. (2010) & $\begin{array}{l}\text { To determine the interactions involved in course-management systems } \\
\text { (CMSs) }\end{array}$ & $\begin{array}{c}\text { L-L } \\
\text { L-I } \\
\text { L-C } \\
\text { L-IF } \\
\text { L-S }\end{array}$ \\
\hline Abrami et al. (2011) & $\begin{array}{l}\text { To discuss issues in the methodology of Bernard et al. (2009) and to } \\
\text { determine how to improve the instructional design based on these results }\end{array}$ & $\begin{array}{l}\text { L-L } \\
\text { L-I } \\
\text { L-C }\end{array}$ \\
\hline Ping (2011) & $\begin{array}{l}\text { To compare the types of student interaction on the online Learning } \\
\text { Management System (LMS) between the undergraduate and postgraduate } \\
\text { level }\end{array}$ & $\begin{array}{l}\text { L-L } \\
\text { L-I } \\
\text { L-C }\end{array}$ \\
\hline $\begin{array}{l}\text { Strickland and Xie } \\
\qquad(2012)\end{array}$ & $\begin{array}{l}\text { To offer guidelines on how to utilize wikis to encourage collaboration and } \\
\text { active learning within and between students in group work for higher } \\
\text { educational settings }\end{array}$ & $\begin{array}{l}\mathrm{L}-\mathrm{L} \\
\mathrm{L}-\mathrm{C}\end{array}$ \\
\hline Zydney and Seo (2012) & To analyze the impact of an online protocol on asynchronous discussions & L-I \\
\hline $\begin{array}{l}\text { Mohammad et al. } \\
\text { (2013) }\end{array}$ & $\begin{array}{l}\text { To introduce and analyze the interaction types, interaction, and interactive } \\
\text { e-learning tools }\end{array}$ & $\begin{array}{l}\text { L-L } \\
\text { L-I } \\
\text { L-C }\end{array}$ \\
\hline $\begin{array}{c}\text { Jumaat and Tasir } \\
\text { (2013) }\end{array}$ & $\begin{array}{l}\text { To identify the types of student online interaction through discussion on } \\
\text { Facebook }\end{array}$ & L-I \\
\hline Aqel (2013) & $\begin{array}{l}\text { To examine the effect of different levels of interaction on instructional } \\
\text { design learners and the instrument to collect data about students' } \\
\text { instructional design course }\end{array}$ & $\begin{array}{l}\text { L-L } \\
\text { L-I } \\
\text { L-C } \\
\text { L-IF }\end{array}$ \\
\hline Prestridge (2014) & $\begin{array}{l}\text { To examine the learning outcomes of students' use of Twitter when used as } \\
\text { a learning tool and to provide insight into how students and teachers } \\
\text { interact in this environment }\end{array}$ & $\begin{array}{l}\text { L-L } \\
\text { L-I } \\
\text { L-C } \\
\text { L-IF }\end{array}$ \\
\hline $\begin{array}{l}\text { Sarapin and Morris } \\
\text { (2015) }\end{array}$ & $\begin{array}{l}\text { To investigate the use and gratification of instructors from the aspect of } \\
\text { social interaction between instructor and on Facebook }\end{array}$ & L-I \\
\hline Schallert et al. (2015) & $\begin{array}{l}\text { To explore the role of a teacher and to investigate the influence of the } \\
\text { presence of teachers in synchronous online discussions }\end{array}$ & $\begin{array}{c}\text { L-L } \\
\text { L-I }\end{array}$ \\
\hline $\begin{array}{l}\text { Kurucay and Inan } \\
\text { (2017) }\end{array}$ & $\begin{array}{l}\text { To determine how learner-learner interactions impact the perceived } \\
\text { learning, achievement, and satisfaction among students in an online } \\
\text { undergraduate course }\end{array}$ & $\mathrm{L}-\mathrm{L}$ \\
\hline Tawfik et al. (2017) & $\begin{array}{l}\text { To assess the type and intensity of learner-learner interaction in an online } \\
\text { Chemistry course provided by Coursera }\end{array}$ & $\mathrm{L}-\mathrm{L}$ \\
\hline $\begin{array}{l}\text { Saadatmand et al. } \\
\qquad \text { (2017) }\end{array}$ & $\begin{array}{l}\text { To examine the interaction between learners and to explore their } \\
\text { perceptions about the presence from the perspective of teaching, social, } \\
\text { and cognitive in an open online course using the Community of Inquiry } \\
\text { (CoI) framework }\end{array}$ & $\begin{array}{l}\text { L-C } \\
\text { L-I } \\
\text { L-L }\end{array}$ \\
\hline Adraoui et al. (2017) & $\begin{array}{l}\text { To analyze the behavior of learners during virtual networking via an online } \\
\text { discussion forum in Moodle using the social learning analytics (SLA) } \\
\text { process }\end{array}$ & $\mathrm{L}-\mathrm{L}$ \\
\hline Panchoo (2017) & $\begin{array}{l}\text { To compare the type of interactions desired by the learners and the actual } \\
\text { learning activities }\end{array}$ & $\begin{array}{l}\text { L-T } \\
\text { L-C } \\
\text { L-I } \\
\text { L-L }\end{array}$ \\
\hline Oyarzun et al. (2018) & $\begin{array}{l}\text { To examine the designed and contextual interactions techniques in } \\
\text { learner-to-learner interaction and to assess their effects on learner } \\
\text { achievement, social presence, interaction quality, and learning satisfaction } \\
\text { in online asynchronous courses }\end{array}$ & $\mathrm{L}-\mathrm{L}$ \\
\hline Annamalai (2018) & $\begin{array}{l}\text { To investigate the patterns of interactions among ESL students during their } \\
\text { online interactions to complete their narrative essays }\end{array}$ & $\mathrm{L}-\mathrm{L}$ \\
\hline Tawfik et al. (2018) & $\begin{array}{l}\text { To study how learner-learner interaction can be influenced by the different } \\
\text { types of cases }\end{array}$ & $\mathrm{L}-\mathrm{L}$ \\
\hline Hayashi (2019) & $\begin{array}{l}\text { To explore the effectiveness of improving learners' interaction using } \\
\text { pedagogical conversational agents (PCAs) in a learner-learner } \\
\text { collaborative learning activity }\end{array}$ & $\mathrm{L}-\mathrm{L}$ \\
\hline
\end{tabular}

* L-C: Learner-Content, L-I: Learner-Instructor, L-L: Learner-Learner, L-T: Learner-Tools, L-S: Learner-Self, L-H: Learner-Human, L-NH: Learner-Non-human (Content, Interface, And Environment), L-I: Learner-Instruction 
Among the different types of students' interaction outlined in all the papers in Table 2, it is worth mentioning the paper of Chou, Peng, and Chang in 2010 which highlighted the 5 types of learners' interactions which were most relevant to the latest shift of learning environment from a traditional classroom setting to online environment. These 5 interactions were considered to be a good representation of all types of learners and provided comprehensive information with regard to interactions that take place on the online social learning platform. This sentiment was echoed by a meta-analysis about online learning interactions by Mutalib et al. (2016)and another paper published by Topal (2016) in which the level of satisfaction and readiness for examination among university students learning via E-courses were explored. We attempt to further describe the 5 types of learners' interactions in Chou et al. (2010) as below, in which learner refers to students and instructor refers to lecturer or teacher.

a. Learner-learner interaction: The interaction that takes place between individual students or when the students are assigned to work in a small group. Communication tools must be made available for students to be able to share and exchange ideas with one another.

b. Learner-instructor interaction: This interaction emphasizes the dialogue or conversation between the learners and instructors. The system must be able to provide an effective communication channel for the purpose of achieving effective interaction.

c. Learner-content interaction: This refers to how the students interact with the subject they are learning or studying. This is necessary in order for them to construct meaning to the study topics and to relate the topics to personal knowledge so that they can apply it for problem-solving. To achieve this, students must be given the right means and tools to be able to interact with all the materials that are available in an online learning environment.

d. Learner-interface interaction: The interface of the online learning tools must be user-friendly so that the students are able to easily access and control the online learning materials.

e. Learner-self interaction: At the end of the learning, students must be able to reflect on the online learning content and process. A new and better understanding derived this interaction can improve the students' ability to pursue their learning objectives and improve their learning progress.

Table 3 shows the number of papers by year of publication. The earliest article identified during the literature search was published in 1989. It is worth highlighting that the majority of papers from 2017 until 2019 focused only on learner-learner interaction.

Table 3. Distribution of Papers by Years

\begin{tabular}{|c|c|c|c|}
\hline Year & Number of Papers & Year & Number of Papers \\
\hline 1989 & 1 & 1994 & 1 \\
\hline 1998 & 1 & 2002 & 1 \\
\hline 2009 & 2 & 2010 & 3 \\
\hline 2011 & 2 & 2012 & 2 \\
\hline 2013 & 3 & 2014 & 1 \\
\hline 2015 & 2 & 2017 & 5 \\
\hline 2018 & 3 & 2019 & 1 \\
\hline Total & & $\mathbf{2 8}$ \\
\hline
\end{tabular}

Table 4 shows the numbers of paper by the type of learners' interactions. The majority of the papers focused more than a single type of learner interaction. Among the different types of interaction, the most commonly reported interactions are learner-learner interaction (24 papers), followed by learner-instructor (19 papers), learner-content (15 papers), learner-interface (5 papers), and 3 papers for learner-self and other types of learner interaction (learner-instruction, learner-environment, and learner-tool) respectively.

Table 4. Distribution of Types of Learner Interactions

\begin{tabular}{|c|c|}
\hline Type of Interaction & Number of Papers \\
\hline Learner-Learner (L-L) & 24 \\
\hline Learner-Instructor (L-I) & 19 \\
\hline Learner-Content (L-C) & 15 \\
\hline Learner-Interface (L-IF) & 5 \\
\hline Learner-Self (L-S) & 3 \\
\hline Others (Instruction, Environment, Tool) & 3 \\
\hline
\end{tabular}

Table 5 shows the type of interactions and strategies to enhance students' interaction during online learning. However, not all the 28 papers discussed the strategies to enhance interaction. Some papers only focused on specific types of learners' interaction whereas others only provided the general strategy without specifying the type of learners' interaction. 
A Review on the Classification of Students' Interaction in Online Social Collaborative

Problem-based Learning Environment: How Can We Enhance the Students' Online Interaction?

Table 5. Type of Interactions and Strategy to Enhance Interaction

\begin{tabular}{|c|c|}
\hline Type of Interaction & Strategy to Enhance Interaction \\
\hline Learner-Learner (L-L) & $\begin{array}{l}\text { Chou et al. (2010) } \\
\text { - Utilizing social tools to improve student interaction } \\
\text { Ping (2011) } \\
\text { - Tools must be able to give instant feedback to stimulate and enhance the learning process } \\
\text { Mohammad et al. (2013) } \\
\text { - The application of video conferencing with E-mail messages } \\
\text { Tawfik et al. (2017) } \\
\text { - Adaptation of a comprehensive Learning Management System, for example, Massive Open Online Course } \\
\text { (MOOC) } \\
\text { Adraoui et al. (2017) } \\
\text {-Learning Management System: Moodle } \\
\text { Oyarzun et al. (2018) } \\
\text { - Role-based scenarios; scaffolding by establishing rules and procedures of interaction; monitor and personalize } \\
\text { interactions by providing timely and meaningful feedback from teachers and peers } \\
\text { Annamalai (2018) } \\
\text {-Social media: Facebook } \\
\text { Tawfik et al. (2018) } \\
\text {-Learning Management System: Blackboard } \\
\text {-Problem based learning } \\
\text { Hayashi (2019) } \\
\text { - Pedagogical conversational agents (PCAs) }\end{array}$ \\
\hline $\begin{array}{l}\text { Learner-Instructor } \\
\text { (L-I) }\end{array}$ & $\begin{array}{l}\text { Moore (1989) } \\
\text { - Provide support and encouragement } \\
\text { Balaji and Chakrabarti (2010) } \\
\text { - Role of the instructor in facilitating the discussion: multiple media of instructions } \\
\text { - Many online activities such as web browsing, reading discussions and reading responses } \\
\text { - Constant interaction and immediate feedback: detailed instructions provided to carry out activities, regular } \\
\text { feedback from instructors } \\
\text { - Assessment in the online environment } \\
\text { - Opportunities for students to share their thoughts with each other } \\
\text { Chou et al. (2010) } \\
\text {-Synchronous communication } \\
\text {-Assignment handling } \\
\text { Ping (2011) } \\
\text { - Tools must be able to give instant feedback to stimulate and enhance the learning process } \\
\text { Zydney and Seo (2012) } \\
\text { - A clear definition of the guidelines and expectations in terms of contributions from the students during learning } \\
\text { - Selection of the types of teaching activities, for example, whether the instructor should give an initial prompt or } \\
\text { direct question during the discussion } \\
\text { - Instructor-facilitated discussions } \\
\text { Mohammad et al. (2013) } \\
\text {-Video conferencing with e-mails } \\
\text { Jumaat and Tasir (2013); Sarapin and Morris (2015) } \\
\text { - Social media: Facebook }\end{array}$ \\
\hline
\end{tabular}




\begin{tabular}{|c|c|}
\hline Learner-Content (L-C) & $\begin{array}{l}\text { Chou et al. (2010) } \\
\text { - Essential connections to link to other educational systems } \\
\text { - Essential connections to link to related learning materials } \\
\text { - Learners' contribution to learning materials } \\
\text { Ping (2011) } \\
\text { - Online quizzes } \\
\text { - To explore the external web links provided } \\
\text { - To make available various types of web-based resources and functions to enhance interactivity capabilities and } \\
\text { to increase feedback on resources } \\
\text { - Good web-based content }\end{array}$ \\
\hline $\begin{array}{l}\text { Learner-Interface } \\
\qquad \text { (L-IF) }\end{array}$ & $\begin{array}{l}\text { Hillman et al. (1994) } \\
\text { - Understand the working procedures with the interface } \\
\text { - Incorporation of activities that teach the students to become familiar with the interface, for example, rotation } \\
\text { between the students to be responsible for interacting with the media, and project assignment that involves } \\
\text { technology application for the purpose of student interaction. } \\
\text { Chou et al. (2010) } \\
\text { - Fixed-frame (menu) design } \\
\text { - Language choice } \\
\text { - Individualized web-browser design } \\
\text { - Sitemap } \\
\text { - Keyword search } \\
\text { - System announcement } \\
\text { - System message } \\
\text { - User guide } \\
\text { - Frequently asked questions (FAQs) }\end{array}$ \\
\hline Learner-Self (L-S) & $\begin{array}{l}\text { Chou et al. (2010) } \\
\text { - Diary and reflective journal } \\
\text { - Note taking } \\
\text { - Electronic portfolio } \\
\text { - Calendar \& schedule reminder } \\
\text { - Task list } \\
\text { - Online quiz for self-evaluation }\end{array}$ \\
\hline $\begin{array}{l}\text { Others (Instruction, } \\
\text { Environment, Tool) }\end{array}$ & Not stated \\
\hline General & $\begin{array}{l}\text { Meeuwisse et al. (2010) } \\
\text { - A healthy learning environment and the cultivation of a sense of belonging among the learners } \\
\text { Abrami et al. (2011) } \\
\text { - Instructional designers need to ensure the overall design objective is user-friendly and easy to use for learners } \\
\text { and instructors. } \\
\text { - Students should be given more guidance as to the reason, the time, and the way to use the tool. } \\
\text { - Training must be offered to show users how to use the tools properly and wisely } \\
\text { - Learning tools and strategies must be incorporated as an important feature of the course to make the course more } \\
\text { effective. } \\
\text { Ping (2011) } \\
\text {-Learning Management System (LMS) } \\
\text { Strickland and Xie (2012) } \\
\text { - Instructors must aim for a purposeful engagement with learners. This can be achieved via communication, } \\
\text { cooperation, collaboration, active learning, feedback, and respect for differences } \\
\text { Aqel (2013) } \\
\text { - Learning Management System: Moodle } \\
\text {-Learning Management System: Massive Open Online Course (MOOC) } \\
\text {-Problem Based Learning } \\
\text {-Social media: Twitter }\end{array}$ \\
\hline
\end{tabular}


The main strategies recommended by most of the past studies to improve learner-learner interaction revolved around the application of social tools such as video conferencing, e-mail, and Facebook. These tools facilitated constant correspondence between students during group work and enabled the provision of immediate feedback to the learners. Another strategy was to apply Learning Management System such as Massive Open Online Course (MOOC) and Moodle and Blackboard. These systems have an in-built set of rules and procedures about the interactions, which allow the monitoring and even customization of the interactions based on the needs of the users. They are also an effective platform for the provision of timely and meaningful feedback from educators and peers. Apart from that, incorporation of problem-based learning strategy and pedagogical conversational agents (PCAs) can also stimulate the learning process.

For learner-instructor interaction, the main strategy involved the provision of support and encouragement by the educators. They can prepare various online activities such as web browsing, reading discussions, field observations, and reading responses. They should also strive to conduct ongoing interaction with the learners in terms of providing the learners with detailed instructions to complete activities. Regular feedback from instructors would increase communication among students and boost greater participation from students. By providing ample opportunities for students to share their thoughts with each other and with teachers via online discussion forum, video conferencing, e-mail messages, or social media such as Facebook, the students can receive immediate feedback and this will stimulate their learning process. However, it is important to establish clear guidelines in terms of expectations towards student contributions, especially for group assignment. Instructors should also discuss with the learners to reach a common understanding in terms of selection of instructional activities, for example, whether the instructor should give an initial prompt or direct question during the discussion. This is essential to encourage instructor-facilitated discussions.

With regard to learner-content interaction, the links to relevant materials were highlighted as the main strategy in enhancing interaction. There should be links made available to other educational systems, learning materials, and multimedia presentation. Students can be given online quizzes after they explored the external web links. Other strategies to consider included the use of online discussion forum, proper selection of web-based resources based on the content, functions, interactivity, and feedback capability of the resources. The web-based content must also be easily accessible, flexible, highly interactive, and easy to navigate. The motivational value and effectiveness of the online learning environment must be preserved to fulfill the needs of students.

Apart from the content, strategies to improve the learner-interface interaction are also a point of interest for the researchers. One of the main strategies proposed in the selected articles was the development of working procedures with the interface that can be easily understood in order to facilitate the communication and active involvement of students. Teaching activities that help students to familiarize themselves with the interface and to accept the technology and content of the instruction should also be implemented. The teaching activities included game-playing, rotation of responsibility to interact with the media among the learners, project assignment that involved the use of technology to interact with others. Apart from that, it is also highly recommended for the interface to incorporate suitable fixed-frame (menu) design, language choice, individualized web-browser design, sitemap, keyword search, system announcement, system message, user guide, and frequently asked questions (FAQ) section about the system.

For learner-self interaction, the strategies suggested included the use of a diary or reflective journal, note-taking, electronic portfolio, task lists, and schedule reminder on the calendar. Online quizzes can also be used for the purpose of self-evaluation. No specific strategies were mentioned by all the 28 papers for the improvement of other types of interaction such as learner-instruction, learner-environment, and learner-tool.

Besides focusing on improvement strategies for specific types of learner interaction, some of the papers also touched on the general strategies that can be considered. These strategies included the cultivation of a healthy learning environment and a sense of belonging. To achieve that, instructional designers must ensure that the overall design objective is user-friendly and easy to use for learners and instructors. Apart from that, students should be given more guidance as to the reason, the time, and the way to use the tool. Very often, practice makes perfect. Thus, potential users must undergo training so that they can learn how to use the tool in a proper way. It is also important to incorporate cognitive tools and strategies as an important feature of the course to make the course more effective. This can be achieved by using learning management systems such as Moodle or MOOC. Wiki tool is also helpful in the designing of a purposeful engagement that emphasizes effective communication and collaboration to stimulate active learning via constant feedback and acceptance for differences in opinions.

\section{Conclusions}

In conclusion, this review identified 5 relevant types of learner interactions that are important in enhancing students' learning performance, namely learner-learner, learner-instructor, learner-content, learner-interface, and learner-self interaction. Comparisons were made between the types of students' interactions and strategies involved in each type of interaction. We also outlined the overall 
strategies to improve those interactions. Apart from a centralized approach, interactions at the individual level should also be encouraged among the students. Instructors should facilitate students' interactions with content, interface, self, and with other students. We believe that findings from this review will contribute to the existing literature on types of interactions and strategies for increasing students' interaction during learning.

\section{Acknowledgements}

The authors would like to thank the Universiti Teknologi Malaysia (UTM) and Ministry of Education (MoE) Malaysia for their support in making this project possible. This work was supported by the Research University Grant [Vote No: Q.J130000.2531.16H55] initiated by UTM and MoE.

\section{REFERENCES}

[1] Abrami, Philip C, Bernard, Robert M, Bures, Eva M, Borokhovski, Eugene, \& Tamim, Rana M. (2011). Interaction in distance education and online learning: Using evidence and theory to improve practice. Journal of Computing in Higher Education, 23(2-3), 82-103.

[2] Adraoui, Meriem, Retbi, Asmaâ, Idrissi, Mohammed Khalidi, \& Bennani, Samir. (2017). Social learning analytics to describe the learners' interaction in online discussion forum in Moodle. Paper presented at the 2017 16th International Conference on Information Technology Based Higher Education and Training (ITHET).

[3] Annamalai, Nagaletchimee. (2018). A Case Study of the Online Interactions among ESL Students to Complete Their Narrative Writing Task. Malaysian Online Journal of Educational Technology, 6(1), 1-17.

[4] Aqel, Magdy. (2013). The effect of different interaction levels on instructional design learners. Procedia-Social and Behavioral Sciences, 103, 1035-1043.

[5] Baharudin, Siti Mastura, \& Jamalludin, H. (2014). Enhancing Students Level of Critical Thinking through Interaction with Problem-Based Learning and Computer Supported The Collaborative Learning Environment. Paper presented at the Proceeding of Fifth International Conference on Intelligent Systems, Modelling, and Simulation. Langkawi, Malaysia.

[6] Balaji, MS, \& Chakrabarti, Diganta. (2010). Student interactions in online discussion forum: Empirical research from'media richness theory'perspective. Journal of interactive online learning, 9(1).

[7] Bernard, Robert M, Abrami, Philip C, Borokhovski, Eugene, Wade, C Anne, Tamim, Rana M, Surkes, Michael A, \& Bethel, Edward Clement. (2009). A meta-analysis of three types of interaction treatments in distance education. Review of Educational research, 79(3), 1243-1289.

[8] Chou, Chien, Peng, Hsinyi, \& Chang, Chun-Yu. (2010). The technical framework of interactive functions for course-management systems: Students’ perceptions, uses, and evaluations. Computers \& Education, 55(3), 1004-1017.

[9] Conejo, Ricardo, Barros, Beatriz, Guzmán, Eduardo, \& Garcia-Viñas, Juan-Ignacio. (2013). A web based collaborative testing environment. Computers \& Education, 68, 440-457.

[10] Fung, Dennis. (2014). Promoting critical thinking through effective group work: A teaching intervention for Hong Kong primary school students. International Journal of Educational Research, 66, 45-62.

[11] Gillies, Robyn M. (2017). Promoting academically productive student dialogue during collaborative learning. International Journal of Educational Research.

[12] Hayashi, Yugo. (2019). Multiple pedagogical conversational agents to support learner-learner collaborative learning: Effects of splitting suggestion types. Cognitive Systems Research, 54, 246-257.

[13] Hillman, Daniel CA, Willis, Deborah J, \& Gunawardena, Charlotte N. (1994). Learner-interface interaction in distance education: An extension of contemporary models and strategies for practitioners. American Journal of Distance Education, 8(2), 30-42.

[14] Hirumi, Atsusi. (2002). A framework for analyzing, designing, and sequencing planned elearning interactions. Quarterly Review of Distance Education, 3(2), 141-160.

[15] Hulsman, Robert L, \& van der Vloodt, Jane. (2015). Self-evaluation and peer-feedback of medical students' communication skills using a web-based video annotation system. Exploring content and specificity. Patient Education and Counseling, 98(3), 356-363.

[16] Jumaat, Nurul Farhana, \& Tasir, Zaidatun. (2013). Students' types of online interaction through Facebook discussion. Procedia-Social and Behavioral Sciences, 97, 353-360.

[17] Ku, Heng-Yu, Tseng, Hung Wei, \& Akarasriworn, Chatchada. (2013). Collaboration factors, teamwork satisfaction, and student attitudes toward online collaborative learning. Computers in Human Behavior, 29(3), 922-929.

[18] Kurucay, Murat, \& Inan, Fethi A. (2017). Examining the effects of learner-learner interactions on satisfaction and learning in an online undergraduate course. Computers \& Education, 115, 20-37.

[19] Kwon, Kyungbin, Song, Donggil, Sari, Annisa R, \& Khikmatillaeva, Umida. (2019). Different Types of Collaborative Problem-Solving Processes in an Online Environment: Solution Oriented Versus Problem Oriented. Journal of Educational Computing Research, 56(8), 1277-1295.

[20] Matcha, Wannisa, \& Rambli, Dayang Rohaya Awang. (2013). Exploratory study on collaborative interaction through the use of augmented reality in science learning. Procedia computer science, 25, 144-153.

[21] Meeuwisse, Marieke, Severiens, Sabine E, \& Born, Marise $\mathrm{Ph}$. (2010). Learning environment, interaction, sense of belonging and study success in ethnically diverse student groups. Research in Higher Education, 51(6), 528-545. 
[22] Mohammad, Nori Motlagh, Sara, Fehresti, Zahra, Talebi, \& Mojtaba, Hesari. (2013). The study of the teacher's role and student interaction in e-learning process. Paper presented at the 4th International Conference on e-Learning and e-Teaching (ICELET 2013).

[23] Moore, M. (1989). Three types of interaction; The American Journal of Distance Education: USA.

[24] Mutalib, Masarrah Abdul, Halim, Noor Dayana Abd, \& Yahaya, Noraffandy. (2016). Meta-analysis on Interaction in Online Learning.

[25] Oyarzun, Beth, Stefaniak, Jill, Bol, Linda, \& Morrison, Gary R. (2018). Effects of learner-to-learner interactions on social presence, achievement and satisfaction. Journal of Computing in Higher Education, 30(1), 154-175.

[26] Panchoo, Shireen. (2017). Learning space: assessment of prescribed activities of online learners. Paper presented at the 2017 International Conference on Platform Technology and Service (PlatCon)

[27] Ping, Teoh Ai. (2011). Students' interaction in the online learning management systems: A comparative study of undergraduate and postgraduate courses. Asian Association of Open Universities Journal, 6(1), 59-73.

[28] Prestridge, Sarah. (2014). A focus on students' use of Twitter-their interactions with each other, content and interface. Active Learning in Higher Education, 15(2), $101-115$.

[29] Rhode, Jason. (2009). Interaction equivalency in self-paced online learning environments: An exploration of learner preferences. The international review of research in open and distributed learning, 10(1).

[30] Saadatmand, Mohsen, Uhlin, Lars, Hedberg, Maria, Åbjörnsson, Lotta, \& Kvarnström, Maria. (2017). Examining learners' interaction in an open online course through the community of inquiry framework. European Journal of Open, Distance and E-Learning, 20(1), 61-79.

[31] Sarapin, Susan H, \& Morris, Pamela L. (2015). Faculty and Facebook friending: Instructor-student online social communication from the professor's perspective. The Internet and Higher Education, 27, 14-23.

[32] Savery, John R, \& Duffy, Thomas M. (1995). Problem based learning: An instructional model and its constructivist framework. Educational technology, 35(5), 31-38.

[33] Schallert, Diane L, Sanders, Anke JZ, Williams, Kyle M, Seo, Eunjin, Yu, Li-Tang, Vogler, Jane S, . . . Knox, Marissa C. (2015). Does it matter if the teacher is there?: A teacher's contribution to emerging patterns of interactions in online classroom discussions. Computers \& Education, 82, 315-328.

[34] Soo, Keng-Soon, \& Bonk, Curt J. (1998). Interaction: What Does It Mean in Online Distance Education?

[35] Strickland, Jane, \& Xie, Ying. (2012). Cooperating or collaborating: Design considerations of employing wikis to engage college-level students Increasing Student Engagement and Retention Using Online Learning Activities (pp. 17-45): Emerald Group Publishing Limited.

[36] Tawfik, Andrew A, Giabbanelli, Philippe J, Hogan, Maureen, Msilu, Fortunata, Gill, Anila, \& York, Cindy S. (2018).
Effects of success $\mathrm{v}$ failure cases on learner-learner interaction. Computers \& Education, 118, 120-132.

[37] Tawfik, Andrew A, Reeves, Todd D, Stich, Amy E, Gill, Anila, Hong, Chenda, McDade, Joseph, . . . Giabbanelli, Philippe J. (2017). The nature and level of learner-learner interaction in a chemistry massive open online course (MOOC). Journal of Computing in Higher Education, 29(3), 411-431.

[38] Topal, Arzu Deveci. (2016). Examination of University Students' Level of Satisfaction and Readiness for E-Courses and the Relationship between Them. European Journal of Contemporary Education, 15(1), 7-23.

[39] Vuopala, Essi, Hyvönen, Pirkko, \& Järvelä, Sanna. (2016). Interaction forms in successful collaborative learning in virtual learning environments. Active Learning in Higher Education, 17(1), 25-38.

[40] Zulkifli, Nurul Nadwa, Abd Halim, Noor Dayana, \& Yahaya, Noraffandy. (2018). THE IMPACT OF ONLINE RECIPROCAL PEER TUTORING ON STUDENTS'ACADEMIC PERFORMANCE. JOURNAL OF ENGINEERING SCIENCE AND TECHNOLOGY, 13, 10-17.

[41] Zydney, Janet Mannheimer, \& Seo, Kay Kyeong-Ju. (2012). Creating a community of inquiry in online environments: An exploratory study on the effect of a protocol on interactions within asynchronous discussions. Computers \& Education, 58(1), 77-87. 